\title{
Hepatitis B and C Seroprevalence in Leprosy Patients
}

\author{
Türkkan Öztürk Kaygusuz¹, Müge Özgüler ${ }^{1}$, Leyla Saltık Güngör², Çiğdem Papila \\ ${ }^{1}$ Elazığ Research and Training Hospital Infectious Diseases and Clinical Microbiology Department Elazıg, Turkey \\ ${ }^{2}$ Elazı̆̆ Research and Training Hospital Public Health Department Elazı̆̆, Turkey
}

\begin{abstract}
Objective: Leprosy is a contagious chronic granulomatous disease and commonly affects the eyes and the internal organs. Leprosy can be classified according to the level of immune response. Leprosy is a disease that is associated with defects in cellular immunity. This is why we have investigated the leprosy patients that were referred to our hospital for chronic hepatitis B and C co-infections.
\end{abstract}

Methods: Fifty patients who were treated in the leprosy unit of Elazığ Research and Training hospital between the dates of June-December 2011 were enrolled to this descriptive study. Macro ELISA assay was performed for Hepatitis B,C and HIV.

Results: Fifty patients who were treated in the leprosy unit of our hospital participated in the study. A total of $8 \% \mathrm{HBsAg}$ presence was noted. A total of 16 Anti HCV presence was noted in the patient group. Anti HCV positivity was determined at seven of 14 patients with tuberculoid form leprosy (50\%) and nine of 33 lepromatous leprosy form (27,2\%).

Conclusion: In conclusion, leprosy patients, especially lepromatous leprosy group, are immunologically vulnerable to HBV and HCV co-infections. Thus, physicians should be aware of HBV coinfections in these patients and education should be given to patients to increase their knowledge regarding risky situations for transmission of the disease. $J$ Microbiol Infect Dis 2015;5(3): 114-118

Key words: Leprosy, Cellulary Immunity, Seroprevalance, Hepatitis B, Hepatitis C.

\section{Lepra Hastalarında Hepatit B ve Hepatit C Seroprevalansı}

\section{ÖZET}

Amaç: Lepra bulaşıcı kronik granülomatöz bir hastalıktır ve sıklıkla göz ve iç organları etkilemektedir. Lepra immün yanıtın derecesine göre sınıflandırılabilir. Bu hastalık, hücresel immünite defekti ile ilgili bir hastalıktır. Bu nedenle, hastanemizde takip edilen lepra hastalarında kronik hepatit B ve C koenfeksiyonlarını inceledik.

Yöntemler: Elazığ Eğitim ve Araştırma Hastanesi Lepra Ünitesi'nde Haziran ve Aralık 2011 yılları arasında tedavi olan elli hasta bu çalışma için değerlendirmeye alındı. Hepatit B ve Hepatit C antijen ve antikorlarının saptanması için Macro ELISA testi kullanıldı.

Bulgular: Hastanemiz Lepra ünitesinde bulunan elli hasta çalışmaya alındı. HBsAg pozitifliği 8\% oranında saptandı. On altı hastada anti HCV pozitifliği saptandı. Anti HCV pozitifliğinin tüberküloid lepra formunda olan 14 hastanın 7 'sinde (\%50) ve lepromatöz lepra formunda olan 33 hastanın 9'unda (\%27.2) olduğu gözlendi.

Sonuç: Sonuç olarak; özellikle lepramatöz lepra formunda olan lepra hastaları immünolojik olarak Hepatit B ve Hepatit C koenfeksiyonlarına duyarlıdır. Bu nedenle; klinisyen bu tür hastalarda koenfeksiyonlar açısından dikkatli olmalıdır ve hastalara, bu hastalığın bulaşmasında rol alan riskli davranışlara ilişkin eğitim verilerek bilgi düzeyleri artırılmalıdır.

Anahtar kelimeler: Lepra,Selüler İmmünite, Seroprevelans, Hepatit B, Hepatit C

\section{INTRODUCTION}

Leprosy is a contagious chronic granulomatous disease that is caused by Mycobacterium leprae, which is also known as Hansen's bacillus and com- monly affects the eyes and the internal organs (liver, lymph nodes, bone marrow, and spleen). It is typically spread with aerosols via close contact with the mouth and nose. Incubation period can be as long as two to six years. ${ }^{1,2}$ Although Leprosy has been well

Correspondence: Müge Özgüler, Elazıg Education and Research Hospital, Department of Infectious Diseases, 23100 Elazıg, Turkey Email: mugeozguler@gmail.com 
characterized, it is still an important morbidity and mortality factor in developing countries. According to the World Health Organization (WHO) data, there are more than 30,000 documented cases in United States of America. Between the years between 1985 and 2006, approximately 14 million people in the world were diagnosed with leprosy and medical treatment was applied. The number of countries where leprosy prevalence over of 1/10,000 was 122 in 1985, while this number has been reduced to 4 in $2006 .{ }^{3}$ It is a known fact that the incidence of Leprosy is higher in populations of low socioeconomical status, poor hygiene, crowded family surroundings, and poor nutrition. Leprosy has been rarely observed in developed Western countries, but it is still present in our country as well as Middle Africa, Asia, India, some Far East Countries, and Central American Countries. ${ }^{1}$

In Turkey, the cumulative number of patients is about 1,044 as determined by the 2014 disease notifications. The majority of these patients has completed treatment and is inactive. The number of patients treated was 21 and the number of patients newly identified in the survey in recent years is approximately six patients. These patients are usually in the environment of older patients (relative) and are long incubation periods. ${ }^{4}$

Leprosy can be classified according to the level of immune response. There are two distinct clinical types of the disease known as lepromatous leprosy and tuberculoid leprosy and a borderline form with hybrid characteristics. In lepromatous leprosy, there are nodules called 'leproma' in which ulceration and necrosis can be seen. Ulcers heal slowly and result in atrophic scars and even tissue destructions. Lesions are commonly observed in soft and hard palate, uvula, under the tongue, and on the lips. Moreover, there can be anterior maxillary involvement and tooth loss. Diagnosis depends on clinical suspicion and should be confirmed by bacteriologic and histological analysis. ${ }^{1,2}$

HBV infection is a world-wide health problem. Four hundred million people are chronically infected with HBV and it is estimated that 1 million people a year have HBV-related deaths. ${ }^{5}$ The September 2010 hepatitis $B$ technical report of ECDC reported the prevalence of hepatitis $B$ in the general population between $2.0-8.0 \%$ in Turkey. ${ }^{6}$ In studies of the prevalence of hepatitis B in our country, HBsAg positivity was reported to nearly $10.0 \%$. But in the recent studies, decreasing HBsAg positivity has been detected over the years (from $5.2 \%$ to $2.97 \%$ ). ${ }^{7}$ In the Elazığ region, the rate of $\mathrm{HbsAg}$ presence was found to be $4.0-10.0 \% .^{8}$

Anti-HCV positivity was found to be $0.95 \%$ in current epidemiological studies, which evaluated 5,471 people between the years 2008 to $2011 .{ }^{9}$ In another study, anti-HCV positivity was determined to be $0.9 \% .{ }^{10}$ There are no studies that present data about the HBsAg and Anti-HCV seroprevalance at leprosy patients in Elazıg.

In a study which was reported from our country, anti-HCV positivity was shown to be $15.2 \%, \mathrm{HBsAg}$ positivity was determined to be $10.8 \%$ and anti-HBs positivity was observed at $50 \%$ in leprosy patients. ${ }^{1}$ Possible causes include the fact that these patients may refer to hospitals many times. In addition, it is known that individuals with anti-HCV positivity go to the dentist for many dental structures that fracture. The carrier may be higher because the risks remain immune deficient in these patients.

Leprosy is a disease that is associated with defects in cellular immunity. Therefore, sensitivity to co-infections is higher in patients with leprosy. ${ }^{2}$ For this reason, we have investigated the leprosy patients referred to our hospital for chronic hepatitis $B$ and $C$ co-infections. We aimed to determine and evaluate HBsAg and Anti-HCV positivity in leprosy patients from our region.

\section{METHODS}

Fifty patients who were enrolled and treated in the Leprosy Unit in Elazığ Research and Training hospital between the dates of June-December 2011 for microbiological and pathological investigations were evaluated retrospectively. Data such as patients' age, disease duration, hospitalization duration, education level, and gender were collected prospectively. Blood samples were taken and each patient was for HBV and HCV. A Macro ELISA assay was performed for Hepatitis B, Hepatitis C, and HIV. In patients with $\mathrm{HBsAg}$ presence, confirmation was performed by Alisei Quality System - SEAC Micro ELISA. RT-PCR was used to detect levels of HBV DNA and HCV RNA. Presence of Anti-HCV was assessed with a Vitros Immunodiagnostic Products Anti-HCV Reagent Pack macro ELISA kit (OrthoClinical Diagnostics, Inc). Data was entered into the SPSS 12.0 program and statistically evaluated.

\section{RESULTS}

Fifty patients who were treated in the leprosy unit of Elazığ Research and Training hospital participated 
in the study. Fourteen of the patients $(28.0 \%)$ were female and $36(72.0 \%)$ were male. The mean age of the patients was 68 years. One or more hypopigmented multiple erythematous macules, nodules, and/or papules were observed on these patients' skin.

We observed loss of sensation in the plaque all of them. Of these patients, 14 (4 females) had tuberculoid leprosy, whereas three (two female) had borderline lepromatous leprosy. The remaining 33 patients (8 female) were diagnosed as having lepromatous leprosy. The average disease duration in tuberculoid, borderline, and lepromatous cases was found to be 39,35 , and 43 years, respectively. HBsAg presence was noted in three of 33 lepromatous leprosy patients and in one of three borderline lepromatous patients. There was no HBsAg presence detected in any of the 14 tuberculoid leprosy patients. A total of $8.0 \% \mathrm{HBsAg}$ presence was noted. In the lepromatous form, HBsAg seroprevalance was found to be $9.0 \%$. In patients with HBsAg presence, the HBV DNA was searched for and the result was negative in all cases. All four patients that had HBsAg presence also had Anti-HBc presence. Isolated Anti-HBc presence was not encountered in any of the patients.
All 46 patients with negative HBsAg were assessed for Anti-HBs presence and 22 of them $(47.0 \%)$ were found to have HBs antigens. Twelve of these had lepromatous leprosy, whereas nine had the tuberculoid form and one had the borderline form. In 15 of these 22 patients $(68.0 \%)$, there was simultaneous Anti-HBc presence in accordance with the previous infection. In the patients in our study, there was $30.0 \%$ chronic hepatitis B infection. In only seven patients (31.8\%), there was isolated anti-HBs presence related to previous immunization. There was no HBV and HCV co-presence in any of the patients.

Anti-HCV presence was noted in 16 patients. Seven of these were from tuberculoid leprosy patients $(50.0 \%)$ and nine was from lepromatous leprosy patients $(27.2 \%)$. Five of these patients were female and 11 were male. There was no HCV antigens detected in any of the borderline lepromatous group of patients. The total rate of anti-HCV presence in the patients was noted to be $32.0 \%$. HCV RNA was sought in patients with anti-HCV presence and in the eight patients. HCV RNA levels were higher than levels that could be detected. Of these eight patients, four were tuberculoid leprosy patients and the remaining four patients had lepromatous leprosy. None of the patients had HIV antigens.

Table 1. HBsAg, Anti HBs, Anti HCV and HCV RNA ratio in the patients

\begin{tabular}{lcccccc}
\hline Clinical form & $\begin{array}{c}\text { Gender } \\
\text { F/M }\end{array}$ & $\begin{array}{c}\text { Disease } \\
\text { duration }\end{array}$ & $\begin{array}{c}\text { HBsAg } \\
\text { presence }(\%)\end{array}$ & $\begin{array}{c}\text { Anti HBs } \\
\text { presence }(\%)\end{array}$ & $\begin{array}{c}\text { Anti HCV } \\
\text { presence (\%) }\end{array}$ & $\begin{array}{c}\text { HCV-RNA positivity in } \\
\text { Anti HCV presence (\%) }\end{array}$ \\
\hline Tuberculoid & $4 / 10$ & 39 & $0 / 14(0)$ & $9 / 14(64)$ & $7 / 14(50)$ & $4 / 7(57)$ \\
Borderline & $2 / 1$ & 35 & $1 / 3(33)$ & $1 / 3(33)$ & $0 / 3(0)$ & $0(0)$ \\
Lepromatous & $8 / 25$ & 43 & $3 / 33(9)$ & $12 / 33(36)$ & $9 / 33(27)$ & $4 / 9(44)$ \\
Total 50 & $14 / 36$ & & $4(8)$ & $22 / 50(44)$ & $16(32)$ & $8(16)$ \\
\hline
\end{tabular}

\section{DISCUSSION}

It is known that at least $1 / 3$ of the world's population has somehow been introduced to HBV and has a healed or chronic infection. There are 350 million chronic hepatitis B cases and the HBsAg presence has been reported to be between $2.0 \%$ and $8.0 \%$ in Turkey and Turkey is in the middle endemic region..$^{6,11}$

There are more than 160 million chronic HCV patients worldwide; however, most are not aware of the disease. This number corresponds approximately to $2.3 \%$ of the world's population. Long-term hepatic exposure to HCV leads to progressive fibro- sis, cirrhosis, and increases in the hepatocellular carcinoma cases. ${ }^{12}$

Co-infections with leprosy, a chronic granulomatous disease, have been under investigation since the 1970s. Hepatitis B and hepatitis C viruses are transmitted by body fluids and generally seropositive and negative individuals share the same environment. This risk has increased in leprosy patients who have been put in the same wards for a long time. In a Rosa et al. ${ }^{13}$ study, a fourfold increase was observed in the HBV risk in hospitalized patients compared to non-hospitalized patients. Both infections were detected more in the lepromatous form in accordance with the literature. 
In another study, $50.8 \%$ of the leprosy patients were found with reactional episodes had HBV and $\mathrm{HCV}$ co-infections. The episodes were more frequent in these patients compared with the non-coinfected group. ${ }^{14}$

The highest HBV and HCV prevalence is expected in the lepromatous form because lepromatous leprosy is characterized with the $\mathrm{Th}_{2}$ type immune response. This pattern is also the immune response that affects the decrease in HBV viral depuration. As a result, patients with lepromatous leprosy cannot generate an adequate immune response for HBV clearance, and this makes them vulnerable to co-infections. ${ }^{15}$ In our study, three of the four patients with HBsAg presence were patients with lepromatous leprosy. Moreover, nine of the 16 patients with Anti-HCV presence were again patients with lepromatous leprosy and these numbers are in accordance with the previous literature findings.

In studies from Brazil, $25.5 \%$ to $39.7 \%$ of the patients with leprosy had a positive HBV marker. ${ }^{15,16}$ In Senegal, a study evaluated 987 leprosy patients and revealed similar results $(23-25.5 \%) .{ }^{17}$

In our study, we did not encounter any isolated Anti-HBc presence and there was a $47.0 \%$ antiHBs presence. In $68.0 \%$ of the patients with HBs antigens, there was an accompanying anti-HBc presence as well. In our study group, $30.0 \%$ had chronic hepatitis B infection. Only in seven patients $(14.0 \%)$, there was isolated anti-HBs presence due to previous immunization.

In a Rego et al. ${ }^{18}$ study, 620 leprosy patients were evaluated. The patients were most frequently found in borderline patients $(48.0 \%)$. Presence of hepatitis B or $C$ virus was documented in $9.0 \%$, and all of the patients have reversal reaction.

In another study by Nigam et $\mathrm{al}^{19}$, HBsAg screening was performed in 80 leprosy patients and the results were compared with a 50 patient control group. HBsAg presence was $7.5 \%$ in leprosy patients and $2.0 \%$ in the control group. ${ }^{19}$ In our study, HBV seroprevelance was found to be $8.0 \%$ in leprosy patients, which is consistent with the previous literature. Another study found the HBsAg seroprevalance to be $6.1-10.0 \%$ in lepromatous leprosy patients whereas; this number was between $2.0-5.0 \%$ in tuberculoid leprosy patients. ${ }^{20}$ In our study, HB$\mathrm{sAg}$ seroprevalance in the lepromatous form was $9.0 \%$ and in accordance with these findings.

In the literature, the co-infection of leprosy and HBV rate varies between $23.0-39.0 \%$. This differ- ence may be due to the geographic region where the study is held. In our study, 50 leprosy patients of which $66.0 \%$ were lepromatous leprosy were assessed and the HBV prevalence was found to be $8.0 \%$.

Our country is in the middle endemicity group with a $2.0-8.0 \%$ HBV rate. In various studies held in our country, there was a $4.0-10.0 \%$ positivity in HBsAg screening. ${ }^{7}$ In Elazığ region, the rate of $\mathrm{HBsAg}$ presence was found to be $4.0-10.0 \%$ in Elazığ. ${ }^{8}$ The rates of our study are in accordance with these findings. Collectively, our results combined with the previous reports are consistent with local endemicity.

Until today, there are studies from Japan and Africa conducted on leprosy patients regarding accompanying anti-HCV presence and the rates in these studies vary between $3.6-9.5 \%$. The $32.0 \%$ $\mathrm{HCV}$ rate that we encountered in our study is higher than the rates reported previously in the literature. The authors believe that the results of this extremely high rate may be due to higher risk of HCV infection in leprosy patients in our country. In addition, the higher rate of paraphernalia and space common use as well as poor education due to the lower socioeconomical status is conceivable. ${ }^{1}$

Rego et al. reported a $5.7 \%$ rate of HCV coinfection in leprosy patients with recurring leprosy reactions..$^{18}$ As a result of the study, they proposed that HBV and especially HCV are risk factors for recurring leprosy reactions in endemic regions.

In Braga et al. ${ }^{21}$ study, the HCV co-infection rate was found to be $3.5 \%$ in the 191 leprosy group and $0.15 \%$ in the control group. Results were found to be statistically significant. This rate was observed to be increasing in hospitalized patients. The majority of these patients had lepromatous leprosy. It was declared by the authors that the HCV prevalence was increased in leprosy patients. This was especially true in patients that were hospitalized, since precaution had to be taken to prevent HCV transmission in these groups of patients.

However, there are only limited studies in our country regarding leprosy and co-infections. In a Altıparmak et al. ${ }^{1}$ study, 46 leprosy patients were assessed. Anti-HCV presence was $15.2 \%$, HBsAg presence was $10.8 \%$, and anti-HBs presence was $50.0 \%$. When our results were compared with this study, we found them to be similar for hepatitis $B$. But our results for Hepatitis $C$ were higher. The reason for this could be that our study was held in a lower education and sociocultural level region and 
that the patients were sharing the common environment for a longer period of time. ${ }^{1}$

The authors believe that the results of this extremely high rate (just like HCV) may be due to: 1 ) higher risk of HBV infection in leprosy patients in our country; 2) higher rate of common use of paraphernalia and space; and 3) a poor education because of the lower socioeconomical status. In our study, the duration of sickness and hospitalization was high especially in the lepromatous leprosy. Longer disease duration often leads to prolonged immune suppression and longer exposure times to infectious agents such as $\mathrm{HBV}$ and HCV. Moreover, we believe that the risk for contact that leads to HCV transmission may be higher. This is one of the reasons why the HCV rate in our study is so high.

In conclusion, leprosy patients, especially lepromatous leprosy group, are immunologically vulnerable to HBV and HCV co-infections. Thus, physicians should be aware of HBV co-infections in these patients. Education should be given to patients to increase their knowledge regarding risky situations for transmission of the disease. Future work will focus on the increasing the awareness and studies in our country regarding this subject.

\section{REFERENCES}

1. Altıparmak E., Koçak M., Kundakçı N. et al. Prevalance of hepatitis $B$ and hepatitis $C$ infection in Leprosy patients. Turkish J Gastroenterology 1999; 10 (3):253-255.

2. Chimenos KE, Pascual CM, Pinol DC, Vinals IH, Rodríguez de RCME, López LJ. Lepromatous leprosy: a review and case report. Med Oral Patol Oral Cir Bucal 2006; 11 (6):474-479.

3. World Health Organization. Weekly epidemiological record, World Health Organization, 2011 (86);389-400.

4. Turkey Directorate of Public Health. Leprosy (Hanseniyazis) http://www.thsm.gov.tr/upload/files/Lepra. (Turkish)

5. Pungpapong S, Kim WR, Poterucha JJ. Natural history of hepatitis B virus infection: an update for clinicians. Mayo Clin Proc 2007; 82:967-75.

6. European Centre for Disease Prevention and Control (ECDC). Hepatitis B and C in the EU neighbourhood: prevalence, burden of disease and screening policies. September 2010. http://ecdc.europa.eu/en/publications/Publications/ TER_100914_Hep_B_C\%20_EU_neighbourhood.pdf
7. Tosun S. Hepatitis B vaccination and hepatitis vaccination results in our country, "Tabak F, Tosun S (eds). Viral Hepatitis". Viral Hepatitis Prevention Society Publication, İstanbul Medical Press, İstanbul, 2013:413-439. (Turkish)

8. Gülaçtı U,Üstün C, Arlıer R, Turan M. The Seroprevalence of Hepatitis B and C among Healthcare Persons in Elazig Harput State Hospital. Konuralp Med J 2013; 5 (3):5-8. (Turkish).

9. Tözün N, Özdoğan $O$, Çakaloğlu $Y$, et al. A nationwide prevalence Sstudy and risk factors for hepatitis A, B, C and D infections in Turkey. The 61st Annual Meeting of AASLD: The Liver Meeting ${ }^{\circledR} 2010$. October 29 November 2 2010, Boston USA, Poster No: 789, Hepatology 2010; 52:1-697A. http:// www.tasl.org.tr/files/file/tasl.

10. Balık I, Tosun S, Tabak F, et al. Investigate the epidemiology of viral hepatitis with mobile team to in our country. (VHSD Bus Project), XI. Ulusal Viral Hepatitis congress, s.44, PS0110, Antalya (2012).(Turkish).

11. Ganem D, Prince AM. Hepatitis B virus infection - natural history and clinical consequences. N Engl J Med 2004; 350:1118-1129.

12. European Association for the Study of the Liver. EASL Clinical Practice Guidelines: Management of hepatitis $C$ virus infection. J Hepatol 2014; 60: 392-420.

13. Rosa H, Costa AP, Ferraz ML, et al. Association between leprosy and hepatitis B infection. A survey in Goiania, central Brazil. Rev Inst Med Trop Sao Paulo 1992; 34:421-426.

14. Motta AC, Pereira KJ, Tarquínio DC, Vieira MB, Miyake K, Foss NT. Leprosy reactions: co-infections as a possible risk factor. Clinics (Sao Paulo) 2012; 67 (10):1145-1148.

15. Leitão C, Ueda D, de Moraes Braga AC, Boldt AB, MessiasReason IJ. Leprosy and hepatitis $B$ coinfection in southern Brazil. Braz J Infect Dis 2014; 18(1):8-12.

16. Ramos JM, Costa e Silva ÁM, Martins RM, et al. Prevalence of hepatitis $B$ and $C$ virus infection among leprosy patients in a leprosy-endemic region of central Brazil. Mem Inst Oswaldo Cruz 2011; 106:632-634.

17. Yvonnet B, Vincelot P, Millan J, et al. Hepatitis B virus infection in lepromatous and tuberculoid patients from Senegal. Acta Leprol 1989; 7:63-6.

18. Rego VP, Machado PR, Martins I, Trindade R, Paraná R. Type 1 reaction in leprosy: characteristics and association with hepatitis B and C viruses. Rev Soc Bras Med Trop 2007; 40: 546-549.

19. Nigam PK, Gupta GB, Khare A. Hepatic involvement and hepatitis B surface antigen ( $\mathrm{Hbs} \mathrm{Ag}$ ) in leprosy. Indian J Dermatol Venereol Leprol 2003; 69 (1):32-4.

20. Machado PR, Johnson WD, Glesby MJ. The role of human T cell lymphotrophic virus type 1 , hepatitis $B$ virus and hepatitis $C$ virus coinfections in leprosy. Mem Inst Oswaldo Cruz 2012; 107 (1):43-8.

21. de Moraes Braga AC, Reason IJ, Maluf EC, Vieira ER. Leprosy and confinement due to leprosy show high association with hepatitis C in Southern Brazil. Acta Trop 2006; 97(1):8893. 